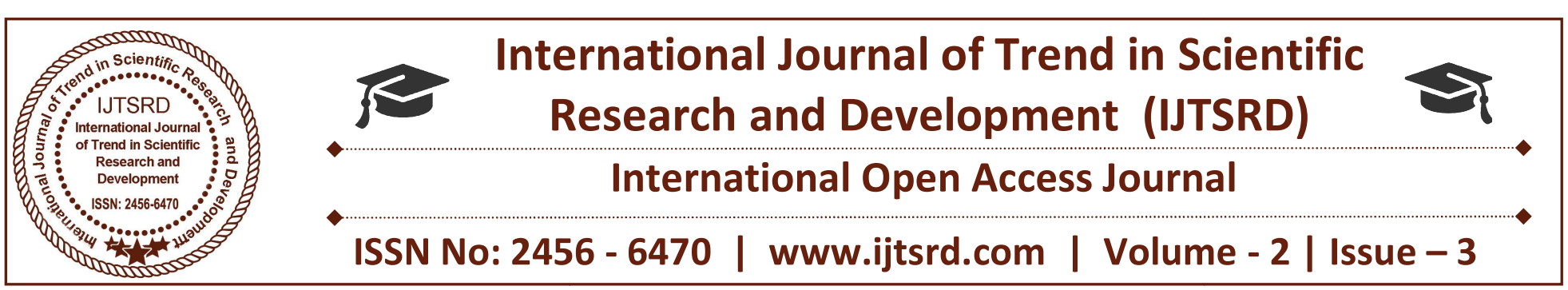

\title{
China-Nigeria Economic Relations: The Need for Greater Resource Management for Development
}

\author{
Zainab Gimba \\ Department of Public Administration, \\ University of Maiduguri, Maiduguri, Nigeria
}

\author{
Sheriff Ghali Ibrahim \\ Department of Political Science and International \\ Relations, University of Abuja, Nigeria
}

\begin{abstract}
The paper examines the relationship that exists between China and Nigeria on economic lines, looking at trade and investment as points of departure. Using the descriptive qualitative research as a method, findings show that, the Beijing consensus works in bringing infrastructure in Africa and paves further ways for Chinese to invest in Nigeria. The paper concludes that, such investment has boosted trade between the two nations and brought about development in such area. The paper recommends opening up and providing more enabling environment by Nigeria for such economic relations to perpetuate.
\end{abstract}

Keywords: China; Nigeria; Economic; Relations; Resource; Management

\section{Introduction}

Over several decades, economies of the world have become greatly connected through international trade and relations. The basis for this integration rests on the fact that nations differ in their resource endowment, preferences, technology, scale of production and capacity for growth and development. Thus the removal of all national barriers to the free movement of international capital which process is accelerated and facilitated by the supersonic transformation in information technology has become imperative (Tandon, 1998). There is a steady increasing breakdown of trade barriers and increasing integration of world market; this is evident from its push of free-market economics, liberal democracy, good governance, gender equality and environmental sustainability among other holistic values; (Akindele, Gidado and Olaopa, 2002).
As global integration of economies progresses and grows more intense, it causes rising efficiency of resource and input utilization in the world economy as countries and regions specialize in line with their comparative advantage and produce goods and services at their lowest opportunity costs (Das, 2007). This gospel has been preached relentlessly by the instruments of globalization namely the International Monetary Fund (IMF), World Bank, World Trade Organisation (WTO) and the G8. The rules and regulations of these agencies have forced many developing countries to adopt free trade policies and liberalization. Nigeria has not been left out of this right from independence; she had opened the door of her economy to international interests, so long as it does not give any polar identity. The Nigerian foreign policies posture of successive governments since her independence has given adequate recognition to both Bilateral and Multilateral Trade/ Economy relations. One of such trade allied of Nigeria has been China. The country's first contact with China unofficially began in the 1950s, 1957 to be precise. This contact would later grow into formidable economic friendship as discussed in subsequent paragraphs of this paper. Moreover, very insignificant trade or economic activities took place during the decade under review (1990- 2000) essentially because this period was dominated by military reigns. Were it not for endless sanctions and restriction imposed on his regime, including of course his demise, much would probably have been achieved in this relation under General Sani Abacha's effort to relate with the Asian giant (Akindele, Gidado and Olaopa, 2002). 


\section{Theoretical Underpinning}

Since the present globalized world operates under the regimes of capitalism and precepts emanating from the paradigm of socio-economic liberalism; we therefore adopt the theory of complex interdependence as a viable tool of analysis in this study. The complex interdependence theory in international relations as a critique of political realism was postulated by Keohane and Nye (1977). It argues that states and their fortunes are inextricably tied together. The concept of economic interdependence was popularized through the work of Richard Cooper. With the analytical construct of complex interdependence in their critique of political realism, Keohane and Nye went a step further and analyzed how international politics and trade relations are transformed by interdependence (Crane and Anawi, 1997). The theorists recognized that the various and complex transnational connections and interdependencies between states and societies were increasing, while the use of military force and power balancing are decreasing but remain important. In making use of the concept of interdependence, Keohane and Nye (1997) also differentiated between interdependence and dependence in analyzing the role of power in politics and relations between international actors. From the analysis, complex interdependence is characterized by the following:

i. The use of multiple channels of actions between societies in interstates, trans-governmental, and transnational relations.

ii. The absence of hierarchy of issues with changing agendas and linkages between issues prioritized.

iii. Bringing about a decline in the use of military and coercive power in relations among sovereign states.

Respectively, complex interdependence is based on specific characteristics that critique the implicit and explicit assumptions of traditional international politics; (that is the superiority of the state and a hierarchy of issues with military force and power, the most important leverage in international relations which traditionally defines political realism in Political Science).

Nye and Keohane (1977) thus argue that the decline of military force as a policy tool and the increase in economic and other forms of interdependence should increase the probability of cooperation among states.
The work of the theorists surfaced in the 1970s to become a significant challenge to political realist theory in international politics and become foundational to current theories that have been categorized as liberalism, neo-liberalism and liberal institutionalism. Traditional critiques of liberalism are often defined alongside critique of political realism, mainly that they both ignore the social nature of relations between states and the social fabric of international society. With the rise of neo-liberal economies, debates, and need to clarify international relations theory, Keohane (2002:2) has most recently described himself as "simply an institutionalist."

The relevance of this theory to the understanding of Nigeria-China trade and economic development in Nigeria cannot be underestimated or overemphasized. The theory will helps us to dispel the general belief and misguided application of dependency theory in the treatment of relations between nations. Moreover, the theory is relevant in the explanation of the contemporary world in which no country can be an island unto itself, since no nation is naturally equipped or endowed with all the resources that it requires in sustaining itself, hence nations must relate with one another in order to survive. The basic contribution of this theory is that it directs attention to the fact that nations are intricately dependent on one another, to the extent that no nation can entirely decide for others. Though this does not dispel the fact that in every relations that there must be winners and losers. Thus, the theory accepts and indicates the realities of unequal gains from trade among two or more interacting nations.

Nigeria-China trade relations are borne out of the fact that none of the two countries possesses absolutely the means of their existence. Hence they have to enter into some form of interdependence upon one another to secure unevenly naturally endowed resources. There exists a form of complementarities between the two countries. For instance, China as an industrializing economy requires the services of the energy that comes from oil (petroleum) and Nigeria on the other hand as an underdeveloped economy requires the products that come from these Chinese companies in order to satisfy the demands of its population. It therefore becomes imperative that the two countries interact and transact across borders. However, since these two countries trade and invest on commodities of various nature and quality (one finished and the other primary product and raw material) it becomes evident that the gains from this 
trade must at one point be tilted to the advantage of one against the other based on the exigencies of the market forces of demand and supply of these tradable commodities. The fundamental implication of this theory to the study is that since in absolute terms the bilateral relations tends to favour China more than Nigeria, there exist the need for the latter to redress the imbalance through renegotiation and improvement in the latter's productive potentials.

\section{Literature Review}

There are abundant studies on China-Nigeria economic relations with divergent opinions. However, Ogunkola et al. (2008) in their book "Nigeria-China Trade and Economic Relations" pointed out the recent developments in China-Nigeria relations presenting Nigeria with both opportunities and challenges. Opportunities to learn from China's growth, development and poverty-reduction strategy and maximizing the spill-over from China's growth in terms of supply of required inputs and services are important for Nigeria's development strategy. This is important for Nigeria given the size of Chinese market and its growth trajectory in recent time. The relation with China also provides the country with alternative markets for sourcing inputs for the industrial sector and finished products for consumption purposes. Hence, it has potential of meeting Nigeria's quest for the much needed diversification of markets for Nigeria's merchandise. The authors noted that Nigeria's exports to China spread over many and varied products and increase from $\$ 20.3$ billion in 2000 to $\$ 44.4$ billion in 2005 . They identify the top 10 exports to China to include: pulp of wood/of other fibrous cellulosic matt; tanning/dyeing extract, tannins and derives; preparation feathers \& down, artificial flower; lac, gums, resins \& other vegetables saps \&extract; oil seed, oleagi fruits miscall grain, seed, fruits; cotton and cocoa preparations; copper and articles thereof; ores, slag and ash; and mineral fuels, oils and product of their distillation. Following the dramatic increase of Nigeria's total imports between $2000-2005$, the country's imports from China rose phenomenally from as little as $\$ 252$ million in 2000 to \$2.3 billion in 2005 (Ogunkola et al, 2008).

In another vein, Pat Utomi, (2009) "China and Nigeria”, he argued that local businessmen commented that they greatly benefitted from the willingness of many Chinese partners to arrange financing for their projects. This was seen as an opportunity to engage in joint ventures while also learning from Chinese business practices. Another incentive for doing business with the Chinese is the willingness of Chinese expatriates to accept the same living conditions offered to local workers. The author opined that though contrary to the previous experienced, Nigerians commented that this was often an impediment when dealing with expatriates from other countries. He argued that the reduced costs of hiring Chinese expatriates made Nigerians more competitive with large Western multinational corporations. Furthermore, for many years, China's economic engagement with Nigeria was limited. Relations stayed at the government-to-government level consisting of aid agreements and development projects (Ogunkola et al, 2008).

However, relations have since greatly expanded into the private sector, with investment often directly encouraged by both the Nigerian and Chinese governments. The Chinese business presence, previously limited to the venturing of Hong Kong textile producers and steel processors, is increasingly being replaced by big commitments from Chinese financial institutions. According to Adeolu, et al. (2010), posits that Nigeria's exports to China increased to $\$ 526.9$ million in 2005 . However, the increase was more than $50 \%$ of which China's share of Nigeria's total exports fell from $1.5 \%$ in 2000 to 0.79 in 2007. In addition, Gregory (2009) in his book "Elephant, Ants and Superpowers: Nigeria's Relations with China" shared similarity with Adeolu that Nigeria's exports to China as at 2005 recorded \$ 527.1 million while China's import to Nigeria the same year rose to 2305.3. More so, Ogunkola et al. (2008) contributed differently that Nigeria's exports to China though spread over many products and increase from $\$ 20.3$ billion in 2000 to $\$ 44.4$ billion in 2005. Holistically, this is one of the areas the researcher intends to contribute to the existing literatures and to also unveil or expose some erroneous notion about China-Nigeria economic relations.

\section{Heckscher and Ohlin Trade Model}

Heckscher and Ohlin trade model examines the differences in countries' resource endowments; hence the exploitation of economies of scale or the availability of increasing returns to scale of production (New Trade theory-see Markusen et al., 1995; Krugman \& Obstfeld, 2008). Invariably, countries endowed with natural resources will tend to 
have absolute and cost advantages which ensure her specialisation in furtherance to its engagement in foreign trade. A handful of other empirical works on international trade that could be credited to Complete specialization are Anderson (1979), Anderson and Wincoop (2003), Bergtrand (1985), and Eaton and Kortum (2002), to mention but a few. Most nations anchored their trade policy towards economic development and strategy by either promoting export or encourage importation of certain products which will go a long way to determine the kind of trade barriers or restriction to be utilized and which areas will be or are covered by various trade agreements and FTAs, international trade agreements and development of free trade zones like the case of China and Nigeria. Therefore, determining the various factors that can improve or deter bilateral trade relations become imperative and fitted as a round peg in a round hole (Tinbergen, 1962; Poyhonen, 1963; Wall, 1999; Nguyen, 2010). Mostly, these authors have made their marks by including both economic and institutional factors that determine bilateral trades.

The rapid increase in China-Nigeria trade and peculiar nature in economic growth between these two nations have prompted this research to consider economic factors that may impair or accelerate this trade relation. A good number of researchers have aired their opinions on bilateral trade determinants. Nguyen (2010) while reviewing Vietnam and 15 partners in trade posited that the exports from previous periods matter to current export volume and went further to buttress that economic size is positively related to trade while trade costs have significant and negative relations to trade, but exchange rates do have significant influence though the magnitude of such influence remains minor. In the same vein, Jinhwar and Orgilbold (2011) considered Mongolia and its 59 trading partners and concluded that trade openness, economic size and development measured in GDP per capita and bilateral trade largely possess significant control on trade across borders. Likewise, Antonucci and Manzocchi (2006) studied Turkey's bilateral trade with EU and the result revealed that economies sizes, per capita income are crucial determinants of trade and Tovonjatorovo and Yinguo (2015) concur that those factors determine export alongside terms of trade and farm gate price which possess negative influence. However, Swenson (2004), Fontagne (1999) and Azu and Nasiri (2015) justified that FDI has considerable impact on volume of trade. Other researches that believed that economic sizes, distances, trade resistance factors, have considerable influence in trade between two countries include (Tinbergen, 1962; Poyhonen, 1963; Linnenman, 1966; Wall, 1999). Deardoffs (1995) agreed that trade impediment factors such as tariff and transport could determine bilateral trade volumes.

Moreover, evidence from Jiranyakul and Brahmabrene (2002) reasoned that real exchange rates, domestic and foreign incomes are principal determinants of Thailand's import and export flow with its major partners in trade, supported by recent views emanating from Sebbagh et al. (2015) which finds that there exists positive impacts of gross domestic product (GDP) and a negative effect with exchange rate, which is not in tandem with Elawady and Abdulkheir (2015) who oppose the fact that GDP of both importing and exporting countries are less important but just like Hailu (2015) also accepts that exchange rate has negative influence on export. Such is the argument in research as each scholar tries to justify peculiar economic situations in relation to bilateral trade.

\section{Chinese Investment Model}

According to Sautman and Hairong (2007), there are factors that made China's relationship with Africa distinctive. Other than aid and migration policies, the "Chinese model" of investment and infrastructure loans known as the "Beijing Consensus" is a very important approach that needs to be discussed. In Ramos's (2004) terms, it is a new attitude towards politics, development, and global balance of power. In general, it values the political and international relations concept of multilateralism, consensus and peaceful co-existence (Wenping, 2007). This approach contrasts with Washington consensus, a neo-liberal paradigm that takes into consideration democracy, good governance, and poverty reduction (Fine and Jomo, 2005- in Sautman and Hairong, 2007).

The Chinese model of investment in essence brings economic growth objectives and foreign policy together guiding trade and investment decisions in Africa along with "no strings attached" financial and technical assistance (Zafar, 2007). Chinese bid competitively for resource and construction projects using investment and infrastructure loans. These loans are often advanced at zero or near-zero percent interest or allow for repayment in natural resources 
(Brautigam, 2003). For example, China offered US\$2 billion in aid for infrastructure projects, thereby securing a former Shell Oil block in Angola by outbidding an Indian proposal. In a similar case, a Chinese firm promised US\$7 billion in investments and rehabilitation of power stations to secure an oil area sought by western corporations (Alden and Davies, 2006). Many Africans view Chinese investment as different from the western investment. According to This Day (2005), the Chinese are not imposing the neo-liberal package of reform usually required by the World Bank under its "conditionality provisions." Chinese aid by contrast comes without strings attached and is seen as supporting initiatives by African states to address development issues not solved by Western investment (Sautman and Hairong, 2007).

\section{Globalization, Trade Liberalization Developing Countries}

and

In the last several decades, there have been ambitious efforts in much of the developing world to liberalize trade and streamline protectionist tariff regimes (Zafar, 2005). Standard trade theory suggests that trade liberalization leads to a more efficient allocation of resources, enhanced productivity, and higher economic growth (Zafar, 2005). Hammouda (2004) in his research conducted on behalf of the Economic Commission for Africa states inter alia:

The unanimous agreement on the beneficial effects on growth and development of trade liberalization goes back to the emergence of the Washington consensus in the early 1980s which emerged in response to the economic crisis affecting most developing countries at the time, triggered by the debt crisis. The Washington consensus sought to tackle that problem through Structural Adjustment Programmes (SAPS) with support from IMF and World Bank to help developing countries restore major macroeconomic balances, ....., the decision to liberalize external trade was part of that broad set of reforms aimed at restoring major macroeconomic balances, promoting growth and improving the global integration of developing countries.

Trade liberalization in and of itself has not yet been un-ambiguously and universally linked to subsequent economic growth, despite the vast literature looking at this link, numerous empirical studies have not found the evidence conclusive (Ahmed \& Suardi, 2009, Dennis, 2006; Rodriguez \& Rodrik, 2001; Tussie \&
Aguo, 2007) but rather the impact of trade liberalization are less clear-cut with little or no positive effect on growth performance in Africa (Ahmed and Suardi, 2009). Academic studies have shown that the main impact of liberalization on trade flow is to increase the demand for export, that is, following trade liberalization, countries tend to buy more than they sell every year and as a result, their trade balance worsens; as import increases, demand in the country for locally produced goods falls, because people are buying imported goods instead, essentially, local producers are priced out of their markets by new, cheaper, better -marketed goods. Melamed (2005) posited that the losses sustained by Sub-Sahara African countries as a result of two decades of trade liberalization under World Bank/IMF economic programmes far exceed the 40 billion dollar worth of debt/relief offered by the G8 summit. Trade liberalization has cost Sub-Sahara African 272 billion dollars over 20 years. Recent evidence from the United Nations shows that countries which liberalized their trade most tended to suffer from increases in poverty. There has been an increased trade relation between Nigeria and China which has raised a number of genuine concerns among policy makers and the business community.

\section{Nigeria Economic Background}

Nigeria's quest for development which has spanned some decades is yet to deliver on the ultimate goal of poverty reduction, despite various plans, programmes, and projects. Analysis of performance on poverty reduction strategy necessarily examines issues in growth and equity simply because growth may be recorded without impacting on the poor. Indeed it is not impossible for growth to have occurred at the expense of equity. Analysis of growth drivers on one hand has identified several factors including macroeconomic environment, political and social environment and investment gap. Some policies are required to attract foreign direct investment (FDI) and to direct such investment into appropriate sectors. As a resource-rich country, Nigeria's economic performance has been unfortunately driven by the oil and gas sector to the extent that even progress recorded towards genuine economic development prior to the discovery of oil in commercial quantity has been virtually eroded. In recent time (2000-2005), the GDP growth was about $5.7 \%$ and the growth in the non-oil sector which contributed about $5.9 \%$ of the GDP. However, the sector dominates the supply of foreign exchange and given that the political economy 
of the country vested this important resource in the hand of the government it also contributes a large chunk of government revenue (Olawale et'al, 2008)

The decline in the agricultural sector performance has been dramatic since the discovery of oil. The manufacturing sector has not performed even better. A few statistics illustrate the poor performance of the non-oil sector. The share of non-oil sector decreased from about $94 \%$ in 1970 to about $52 \%$ in 2004 . The decrease affected all the sectors (agriculture, industry, and services) but in different magnitude. Agriculture GDP declined from about $41 \%$ to about $17 \%$ over the same period. The decline in the services sector was from about $45 \%$ to about $27 \%$ during the period under review. Nigeria's non-oil sector is inefficiently servicing the domestic market as non-oil export is negligible (about 1\% of the GDP in 2005) (Olawale et'al, 2008). Nigeria's domestic market is vast but very small for modern day technology. Thus, there is the need for seeking favourable external market at regional as well as at global level. Negotiations of the trade agreements are expected to take these constraints into consideration. Indeed, for Nigeria within the border issues are relatively more important than seeking for more favourable market access conditions. It is in this vein that aid-for-trade concept is more relevant to the country. A critical element in enhancing the performance of non-oil sector as well as ensuring effective supply response to market opening is investment in infrastructure which also in turn enhances private investment. Thus, private investment and investment in the public sector of the economy is one of the factors for ensuring sustainable development (World Bank 2007; Olawale et'al, 2008).

\section{Background of China- Nigeria Economic Relation}

Nigeria's initial contact with the Chinese was through Egypt. It is on record that Chan Hanq Kang, commercial officer in the Chinese Embassy in Cairo, established unofficial trade links with Nigeria, along with Tunisia, Libya, Ghana, Ethiopia, Tanganyika (now Tanzania) in 1957 (Utomi, 2008). However the two countries formally established diplomatic relations in February 1971. That same year, Nigeria and other developing countries from Asia, Africa and Latin America helped, despite American opposition, to tip the scales in favour of Beijing's 21-year campaign to win world recognition as the one true government of China. On 25 November 1971, the PRC officially replaced the Republic of China
(Taiwan) in the United Nations and on the UN Security Council. (Alobo, 2014, Owoeye (1986:71).

With Deng Xiaping's reform policies of the 1970s and 1980s, China's dramatic growth and modernization, attendant industrial energy and market expansion needs brought it into greater contact with Africa (Utomi 2009:2). This new expanded presence offered a partnership seen by Nigeria as an alternative model to Western relationships mainly from Europe, America and Canada. This resulted in the establishment of diplomatic relations at ambassadorial level in 1971 (Utomi 2009:2, Kwanashie (2000), and since then it has achieved a smooth and steady development. In the 30 years that followed, diplomatic relations between the demographic giants of Asia and Africa produced little of economic consequence. While China was transforming into an economic power, for Nigeria, the 1980s and 1990s were marked by a series of military coups. In 2001, the two countries signed agreements on the establishment of a Nigeria Trade Office in China and a China Investment Development and Trade Promotion Centre in Nigeria. The intergovernmental Nigeria-China Investment Forum was then founded in 2006. From less than USD 2 billion in 2000, trade between China and Nigeria reached nearly USD 18 billion just ten years later. Between 2003 and 2009, Nigeria was a top destination for Chinese Foreign Direct Investment on the continent, second only to South Africa. Its attractions are clear: vast energy reserves and a large domestic market of 150 million inhabitants with growing disposable incomes. This neck deep relation is understandable since Nigeria had just freed itself from the status of a pariah state which Nigeria's burdensome military dictatorship forced on it (Udeala, 2010). For Nigeria, incentives lie in China's own successful economic transformation, its capacity to deliver large-scale infrastructure projects and, more importantly, its ability to finance them.

While initially driven by its vast demand for energy resources, China's involvement in Nigeria has since expanded far beyond oil. China's public and private companies are making forays into Nigeria's manufacturing and information and communication technologies sectors. They are developing two special economic zones within Nigeria and are building new roads, railways and airports across the country. China is also known for its policy of offering unconditional aid - what it calls "co-operation" - to help in reaching development goals. In an effort to boost Nigeria's agricultural output, hundreds of Chinese specialists 
are bringing new techniques and technology to bear. Recent developments in China and Nigeria relationship are not unconnected with the renewed ties between the two giants. Although, China and Nigeria established diplomatic tie in 1972, the last three or so decades have witnessed unprecedented renewed positive and mutually beneficial developments. Indeed between 1999 and 2014, diplomatic visits and signing of Memorandum of Understanding at the highest level were recorded. Both countries stand to gain significantly from their economic engagement, but a few stumbling blocks could impede progress. Nigerians have expressed dissatisfaction with the labour practices of Chinese companies, the quality of cheap imported goods and the impact of those imports on domestic producers. Though Chinese investors are less risk averse than others, Nigeria's political unpredictability could eventually dissuade them from continued investment. Despite disputes on the attribution of responsibility for counterfeit and smuggled goods, the two countries continue to assert their mutual friendship and good will (Utomi 2009:2, Kwanashie (2000).

\section{Scope of Sino-Nigeria Economic Relations between 1990- 2000}

Although Nigeria had entered into Bilateral Trade agreement with China as early as 1971, there were no significant economic activities between both Nations until 1995 when late General Sani Abacha (in power from 1993 to 1998) revived the economic ties by initiating contact with the Chinese government early in his rule. The Nigerian-Chinese Chamber of Commerce was founded in 1994. The Sani Abacha government diplomatically commenced the steps that drew China closer to Nigeria.

The impact of sanctions imposed by the United States and its Western Allies on Nigeria by 1995 because of its human rights abuses led the government to look "East". However, trade statistics showed that the balance had been heavily weighted in favour of China, which imported goods and services, of a value of not more than N39.360 million from Nigeria, as compared with Nigeria's import of N5.388 billion from China in 1996 (Chibundu , 2000:20). Ogaba (1999) noted that during the diplomatic visits made by leaders of both countries in trade agreements between the two countries were signed; Chinese companies were awarded contracts to become involved in oil production in Nigeria, the refurbishment of the longneglected Nigeria railway corporation, the dredging of seaports at Calabar and Warri, and development of mass housing projects. He further stated that the trade between Nigeria and China in 1995 reached \$ 10 million doubling the 1994 figure, indicating an increased economic interaction between the two countries.

Ogaba (1999) again noted that the growth of the Chinese economy in the last one and half decade has been phenomenal and holds some attraction for the Nigeria economy. The significant growth of Chinese economy which outstripped all other countries not only in the Asian-pacific, but in the entire world has made it an important country. Ogaba observed that it is as a result of China's economic performance in recent times that the Nigerian government under General Sani Abacha considered it imperative to establish trade partnership with China, and that the Chinese ceconomy is a model for the Nigerian economy which was undergoing guided transformation. Jide (1998) wrote that Nigeria embraced China and abandoned its traditional trading partner of the west with consequent serious economic decline. This has opened a window of opportunity for a careful assessment of the future of its foreign relations as well as graphically underscoring the fact that one cannot really separate foreign and domestic policies. In 1995 the China Civil Engineering Construction Corporation (CCECC) won a \$529 million contract to rehabilitate the Nigerian railway system, and the former premier of China's State Council, Li Ping, visited Nigeria in 1997, signing protocols relating to power generation, steel and oil (Utomi, 2008; Ogunsanwo, 2008). 
International Journal of Trend in Scientific Research and Development (IJTSRD) ISSN: 2456-6470

Table 1.0 Nigeria-China Trade Summary 1990-2001 (N Million)

\section{Year Exports Imports Trade Total}

\begin{tabular}{|l|l|l|l|}
\hline Year & Export & Import & Trade Total \\
\hline 1990 & $44,870,000$ & $1,030,633,000$ & $1,075,503,000$ \\
\hline 1991 & $21,073,000$ & $659,302,000$ & $680,375,000$ \\
\hline 1992 & $24,619,341$ & $5,448,545,779$ & $5,473,165,120$ \\
\hline 1994 & N/A & N/A & N/A \\
\hline 1995 & $325,329,674$ & $10,989,908,928$ & $11,315,338,602$ \\
\hline 1996 & $199639,360,000$ & $5,388,289,053$ & $5,427,659,053$ \\
\hline 1997 & $12,671,356,489$ & $39,890,423,116$ & $52,561,789,605$ \\
\hline 1998 & $12,233,411,035$ & $40,667,431,116$ & $52,900,842,141$ \\
\hline 1999 & $10,671,356,489$ & $39,890,423,259$ & $50,561,779,758$ \\
\hline 2000 & $14,125,595,743$ & $25,693,468,606$ & $39,819,064,349$ \\
\hline
\end{tabular}

Source: Bureau of Statistics, Abuja Annual Report 1990-2001

Table 1.0 above shows a summary of Nigeria-China trade between 1990 and 2001. The table indicates a consistent and rapid increase in the volume of trade between Nigeria and China. Therefore, we found that bilateral trade agreements between Nigeria and China within the period under review impacted positively on the volume of trade between the two countries.

It was not until the return of democratic rule in Nigeria that economic relations began to develop in earnest. Olusegun Obasanjo's election in 1999 coincided with the start of a new Chinese orientation toward Africa in 2000. The first ministerial conference of the Forum on China-Africa Cooperation was held in Beijing in October 2000. Obasanjo did not attend, but senior Nigerian representatives did, and in the same year CCECC was awarded a tender to build 5000 housing units for athletes participating in the eighth annual All-African Games in Abuja, which were duly built (Zhan, 2007 \& Utomi, 2008). In 2001, the two countries signed agreements on the establishment of a Nigeria Trade Office in China and a China Investment Development and Trade Promotion Centre in Nigeria (Bukarambe, 2005). During Obasanjo's second term (2003-2007), both China's President Hu Jintao and Prime Minister Wen Jiabao visited Nigeria, and Obasanjo made two official visits to Beijing. Various other ministeriallevel visits conducted during this time allowed the two countries to develop and intensify mutual friendship and familiarity.

From less than USD2 billion in 2000, trade between China and Nigeria reached nearly USD18 billion just ten years later. Between 2003 and 2009, Nigeria was a top destination for Chinese Foreign Direct Investment on the continent, second only to South Africa. Its attractions are clear: vast energy reserves and a large domestic market of 150 million inhabitants with growing disposable incomes. For Nigeria, incentives lie in China's own successful economic transformation, its capacity to deliver large-scale infrastructure projects and, more importantly, its ability to finance them.

\section{Perspectives on China's Investment in Nigeria}

Unlike their national leaders who are supportive of partnerships, China's increased presence in Nigeria has been questioned by several scholars and societal organizations (Konings, 2007). While some scholars see China's economic growth as a positive development model for the third world (Alden, 2005), others look more critically at China's behavior on the continent and sees its parallels to the neo-colonial past (De Lorenzo, 2007). Here, the Hood and Young (1981) model that evaluate multinational activity based on social, competitive, trade, etc. criteria has been adopted.

\section{Social Effects}

Assessing the advantages and disadvantages of Chinese involvement in Nigeria may not be so simple. Nigeria's economic growth in recent times, especially hitting its highest ever may partially be attributed to Chinese investment (Hanson, 2008). In addition, the roads, bridges and dams built by China are important contributors to the nation's infrastructure. On the 
other side, the relationship has emboldened the governments to limit their progress towards political and economic reform.

\section{Trade Effects}

There are even more controversial points related to the trade, commerce and social areas. According to Kaplisky et al. (2007), trade in Africa especially in Nigeria is impacted in two ways. One aspect is the competition in internal markets for domesticallyoriented manufacturers, and another is competition in external markets from export-oriented industry. The balance of trade favors China as local industries and merchants have been hit hard by the flood of cheap Chinese wholesale and retail shops used to establish networks to sell goods (Alden, 2005, pp 156). Moreover, Nigerian producers cannot compete with Chinese companies even in African markets since Chinese manufacturers have low production cost and market prices (Tull, 2006).

\section{Competitive Effects}

The use of Chinese labor, rather than local workers in Chinese sponsored projects in Nigeria has been criticized locally (Alden, 2005). De Lorenzo (2007) also reiterates that, what is worrisome is the impact of Chinese competition on Nigeria enterprises and exports. In Nigeria, the imported textiles have forced local factories to close.

\section{Unemployment Effects}

These challenges are not limited to the competition. According to Anshan (2007), with the flow of goods from China, conflict over labour practice and market strategies is turning out to be an important issue. The preference to hire Chinese nationals and long hours of work expected by Chinese managers is causing conflict with local labour laws and cultures. In addition, company practices lead to discontent in communities who perceive that Chinese companies are not contributing enough to increase local employment and strengthen the local economy. Another conflict is the quality of Chinese goods which is cheaper and of better quality than locally produced ones.

\section{Moral Effects}

Zweig and Jianhai (2005) stated that "Beijing's resources-based foreign policy has little room for morality". After all, some of the very rich resources are found in nations with a history of ineffective governance. China has established relations with rogue nations, at times mired with violent reactions from the citizens of those nations. Some examples can be found in their experiences in Sudan, Nigeria, Ethiopia, and Zambia. For instance, in Zambia's copper belt of Chambishi, protesting employees were sprayed with gunfire by Chinese supervisors (Trofimov, 2007).

\section{Challenges of Nigeria -China Economic Cooperation}

One of the major challenges is the present state of infrastructural facilities especially in the areas of power, rail network systems and communication in Nigeria which is very poor and if urgent steps are not taken to address these, it may get worse. And until Nigeria rises up to these challenges, foreign investment inflow will continue to elude the country. Another challenge is the wide trade imbalance that continues to be in favour of China. In 2005, the total value of trade between Nigeria and China was US\$2.5 billion. Out of this Nigeria made only US\$400million while China's share amounted to US2.1 billion (Alli 2007:5). With the great need of the Chinese for agricultural raw materials which the Chinese need, it is already clear that Nigerian government should intensify efforts to promote industrial and agricultural production and their export to China (Alli 2007:5).

Attempts by Nigeria to participate in global economy has to a large extend been stifled by poor technology. As a result China has become its best partner in terms of technological transfer. However, concern has been raised over the role of China in this regard (Akongbowa 2008:18), increasingly, the technology transferred from Chinese FDI is insignificant because most of the Chinese firms bring into the country complete equipment with Chinese technicians. This was the case with the Zamfara state government. The government signed a US\$250 million agreement for the construction of three new processing and smelting factories in the state. Under the joint venture projects, Chinese companies had 90 percent in each of the joint venture projects while the Zamfara government had 10 percent. The Chinese firms will design the projects, select appropriate technology, buy all the equipment, install and run them while Zamfara government will provide land, acquire both exploration mining licenses, provide security for the Chinese investment and employ 5,000 local miners (Thisday July 7, 2010, p.70). 
China has complained about the high rate of insecurity arising from pronounced social violence. There are instances of kidnapping of foreign investors, properties and investments of foreign investors come under direct attack. For instance, oil bunkering and the destructions of oil installations in the Niger-Delta region. This endless insecurity in Nigeria which ranges from ethnic conflicts to religious clashes will no doubt overshadow whatever incentives that the Nigerian government may provide to attract foreign investment. In April 2006, the Movement for the Emancipation of the Niger Delta condemned China for its multi-billion investments in oil fields in the South of Nigeria. The group warned that Chinese investors would be treated as "thieves" and threatened new attacks on oil workers and infrastructure (Jonathan 2009:15).

\section{Current bilateral trade transactions between Nigeria and China}

While there has been consistent increase in trade over the years, there is trade imbalance in favour of China because it exports more products than what it imports, unlike Nigeria, which relies more on the importation of goods for domestic consumption. This suggests the need to examine the structure of tariff and non- tariff barriers facing Nigeria's exports to China and the constraints being faced by Nigerian entrepreneurs in responding to international trade opportunities

\section{Comparison of Trade Indicators \& Statistics between Nigeria \& China}

Under Institutional framework, global ranking points to a weak institutional environment in Nigeria with a ranking of 125th, 120th, 79th, and 119th position in respect of "Ease of doing business, wastefulness of government spending, transparency of government policies and diversion of public fund" respectively out of 133 countries as against China's of 39th, 35th, 32nd and 55th in the same order. Nigeria ranking on infrastructural development indices is very poor and attention needs to be diverted in the development of critical infrastructures like electricity, port, roads and railway. Nigeria needs to improve its funding on basic and tertiary education more than it presently does for sustainable development of its manpower. Nigeria fared well in technology readiness as it ranked averagely on indices such as availability of latest technology and firm-level technology absorption which however have not translated to high-technology and competitively priced products on the international market.

Nigeria was also not found wanting in her capacity for innovation and companies continued spending on research and development, there is however a disconnect between universities and the industry, which is evidenced by the country's 87 th position in ranking as against China's $23^{\text {rd }}$. Government procurement of advanced technical products and the quality of scientific research institutions are abysmal and need to be focused on. Nigerian economy is in respect of the sub-standard nature of the Chinese goods being imported into the country. In terms of the lack of competitiveness of Nigerian goods with China made-goods, power failure, shortage of affordable credit to procure input and multiple taxation ranked first, second and third respectively as the factors responsible for the un-competitiveness of the Nigerian products. All the respondents agreed that local manufacturing firms must be protected through tariff and subsidies against the invasion of sub-standard, subsidized foreign products.

\section{CONCLUSION}

This study is focused on the Nigeria-China trade relations and economic development in Nigeria (1990-2000). The paper concludes that the NigeriaChina bilateral trade agreements have enhanced the volume of Chinese trade with Nigeria. Also, the study found that the increase in the volume of trade between China and Nigeria enhanced economic development (even though not as significantly as the subsequent years). Also, there have been enormous contributions of Chinese firms, businesses and financial institutions in employment generation, human capital development, and poverty reduction through infrastructural development, loans and aid. While the possibilities certainly exist for Nigeria to derive higher value from China's growing influence, Nigeria has not fully capitalized on the potential benefits. While the official trade records between Nigeria and China is impressive, they fail to capture the complete picture of trade between them. In addition to the recorded trade, there is a significant amount of unrecorded trade, particularly in Chinese goods.

Most of the smuggled imports are said to arrive via neighbouring countries, which have long porous borders with Nigeria. China has been involved in Africa as trading partners, development partners' comrades, and immigrants. China has engaged in 
Africa's territory and strengthened ties through diplomacy to gain access to natural resources in Africa.

\section{RECOMMENDATIONS}

Following findings from the study, the following recommendations have been advanced:

1. Nigeria should create an enabling business environment to encourage Chinese and other investors. It must address basic infrastructural impediments such as provision of electricity, transport and better telecommunication facilities.

2. Nigeria should use China's thirst for oil to extract concessions in areas vital to Nigeria's interest. China should be encouraged to strengthen and improve its co-operation with Nigeria in engineering projects and technological cooperation. Nigeria should identify and systematically develop areas it has comparative advantage over China in order to maximise benefits from this trade.

3. Nigeria should undertake a comprehensive overhaul of its foreign policy and use it for the aggressive pursuit of economic security and mutually beneficial international cooperation bilaterally and internationally.

4. The Nigerian government should move beyond arrangements that focus solely on the

Petroleum sector. High commodity prices are only a temporary vehicle that can be utilized to drive Nigeria's economy into a more economically diversified state, the true mechanism for sustained growth.

5. The Nigerian government should make concerted effort at policing its borders to prevent

the influx of smuggled goods into the country. This will encourage local manufacturing.

6. In addition, for Nigeria-China trade relations to wear a more acceptable face, concrete

steps must be taken to fully implement the existing trade agreements and initiate fresh trade agreements to cover areas that will enhance Nigeria's export of non-oil products to China. This will be to the mutual benefit of both countries. By this initiative, Nigeria will take advantage of this bilateral interaction to improve on its domestic economy rather than being a mere provider of raw materials and importers of finished goods from China.

\section{REFERENCES}

1. Abbah, T. (2006). China-Nigeria economic cooperation in whose interest. Leadership, Sunday, June 4, 2006.

2. Abdol S. S. (2009). China's exchange rate policy and the United States' trade deficits. Journal of Economic Studies, 36(1), 36-65. tp://dx.doi.org/10.1108/01443580910923795

3. Abiodun S.B., et al, China-Nigeria Economic Relations: Scoping Studies on China-Africa Relations, Trade Policy Research and Training Program (TPRTP) Ibadan, Nigeria, 2008

4. Abua, J. (2008). From China, a harvest of agreements. ThisDay Newspaper, 16 November.

5. Adeniyi, O. (2011). Power, politics and death: A front-row account of Nigeria under the late President Yar'Adua. Lagos, Nigeria: Kachifor Publishers Limited.

6. Adeolu O. et al, Impact of China-Africa Trade Relations: The Case of Nigeria. The Africa Economic Research Consortium, January 2010 p. 3,4

7. Adewuyi, A. ., Alarudeen, A., \& Kareem, O. (2010). Impact of China-Africa Trade Relations: The Case of Nigeria. African Economic Research Consortium (AERC), Nairobi, Kenya.

8.

9. Ajayi S. I. (2006), "The Determinants of FDI in Africa: A Survey of the Evidence', In: S. Ajayi, Ibi, (ed.) FDI in Sub-Saharan Africa: Origins, Targets, Impacts and Potential, African Economic Research Consortium; Kenya: Nairobi

10. Akongbowa, B. A. (2008). Nigeria-China economic cooperation: Conceptualization, contending issues and prospects and its implications for the West African sub-region. 12th EADI General Conference, Global Governance for Sustainable Development, Geneva 24-28 June 2008, p.9

11. Alli, W. O. (2007). The prospects and challenges of engaging China. Lagos: NIIA.

12. Alobo O.J, (2014) Nigeria-China Trade Relations and Economic Development in Nigeria, 20012013 A Research Project Submitted to the Department of Political Science, Faculty of the Social Sciences, University of Nigeria Nsukka in Partial fulfilment of the Requirements for the 
Award of Master of Science Degree (M.Sc.) in International Relations

13. Arkar, T. (2002). Development law and international finance. 2nd ed. Kluwer law International.

14. Bergstrand, J. H. (1985). The gravity equation in International trade: Some microeconomic foundations and empirical evidence. The Review of Economics and Statistics, 67(3), 474-481. http://dx.doi.org/10.2307/1925976

15. Bhagwati, J. (1958). Immiserizing Growth: A Geometric Note. Review of Economic Studies, 25(3), 201-205. www.ccsenet.org/ijef International Journal of Economics and Finance Vol. 8, No. 3; $2016 \quad 223$ http://dx.doi.org/10.2307/2295990 Daniel, G. H.,

16. Bukarambe, B. (2005), "Nigeria-China Relations: The Unacknowledged Sino Dynamic", in U.J.

17. Bukarambe, B. (2007). Nigeria-China relations: The unacknowledged sino-dynamics. Paper Presented at the Conference on Nigeria and the World after forty years: Policy Perspectives for a New Century, NIIA, Lagos, 2001, p.

18. Chibundu, V. N. (2000). Nigeria-China foreign relations, 1960-1999. Ibadan: Spectrum Books.

19. Coe, M. \& Helpman, V. (1995), A Study on Economic Development. Boston: Prince Precious

20. Eaton, J., \& Kortum, S. (2002). Technology, Geography, and Trade. Econometrica, 70(5), 1741-1779. http://dx.doi.org/10.1111/14680262.00352 Elawady, S. I. A., \&Economic Research Consortium, Ibadan: University of Ibadan.

21. Fontagne, L. (1999). Foreign Direct Investment and International Trade: Complements or Substitutes? OECD Science, Technology and Industry Working Papers, 3.

22. Gregory, M. S. (2009). Elephants, Ants and Superpowers: Nigeria's Relations with China, China in Africa Projects. South African Institute of International Affairs, September.

23. Hailu, Z. A. (2010). Impact of Foreign Direct Investment on Trade of Africa Countries. International Journal of Economics and Finance, 2(3), 114-121. http://dx.doi.org/10.5539/ijef.v2n3p122House Press Institute of International Affairs, September International Affairs. 108

24. Jinhwan, O., \& Orgilbold, T. (2011). Mongolia's International Trade: Impact of its Geographical Location. The Journal of Econometric Study of Northeast Asia, 7(2), 69-82.
25. Jiranyakul, K., \& Brahmabrene, T. (2002). An analysis of the determinants of Thailand's exports and Imports with major trading partners. Southwestern Economic Review, 29(1), 111-121.

26. Johansen, S., \& Juselius, K. (1990). Maximum likelihood estimation and inference on cointegration with application to demand for money. Oxford Bulletin of Economics

27. Jonathan, E. L. (2010). Are the forces that cause China's trade surplus with the USA good? Journal of Chinese Economic and Foreign Trade Studies, 3(1), 43-53.

28. Jonathan, H. (2009). China's new security strategy for Africa. Parameters, June 2009, 23-24: 15

29. Kaplinsky, R. (2007), "The Impact China and India on the SSA: A Methodological Framework', Paper prepared for AERC, March.

30. Krugman, P., \& Obstfeld, M. (2008). International Economics: Theory and Policy. Pearson Education Asia Ltd and Tsinghua University Press.

31. Kwanashie, M. (2007). Sino-Nigeria relations: Implications for trade. Roundtable on NigeriaChina Relations: Lagos, Economic and Political Dimensions by Nigerian Institute for InterNational Affairs (NIIA), 26 September 2007, p.2, 7

32. Lawal. Africa's Business and Development relationship with China:Seeking Moral and Capital Value of the last Economic frontier, Hong Kong, 2009 p. 8.

33. Linnemann, H. (1966). An Econometric Study of International Trade Flows. Amsterdam, NorthHolland Pub. Co.

34. Maiwada, S. (2015). Chinese Trade and Investment in Nigeria's Agricultural sector; A critical Analysis. American International Journal of Social Science, 4(2), 277-287. Marathon

35. Markusen J. R. (1995). The Boundaries of Multinational Enterprises and the Theory of International Trade. The Journal of Economic Perspectives, $9(2), \quad 168-189$. http://dx.doi.org/10.1257/jep.9.2.169

36. Nabine, D. W. (2009). The Impact of Chinese Investment and Trade on Nigeria Economic growth. African Trade Policy Center No. 77. http://dx.doi.org/10.5539/ijef.v2n4p122

37. Nabine, D.W. (2009). The impact of Chinese investment and trade on Nigeria economic growth. African Trade Policy Centre, No. 77, p.1

38. Ogunkola, E.O, A.S. Bankole and A. Adewuyi (2008) "China-Nigeria Economic Relations". 
39. Ogunkola, O. E. (2008). Nigeria-China trade and economic relations. Ibadan: Nigeria African Research Consortium (AERC) Publishers.

40. Ogunkola, O. E. Abiodun S. et al (2010). NigeriaChina economic relations. Zenith Economic Quarterly, Vol.5, No.4, October 2010, p.68. Zenith Bank Publication.

41. Ogunsanwo, A. (1974), China's Policy in African, 1958-1971, London: Cambridge University

42. Ogunsanwo, A. (2007). Nigeria and China. Paper Presented at a Seminar on China Africa Relations in South Africa, NIIA, Lagos, September 2007, p.6

43. Ogunsanwo. A. (2008). A tale of two giants: Nigeria and China. In Kweku, A. \& Sanusha, N. (eds.) Crounching tiger, hidden dragon? Africa and China. Kwazuhi Natal, Capetown South Africa: University Press.

44. Rindap, M. R. (2015).An Assessment of NigeriaChina Economic Relations from 1999-2014. International Journal of Arts and Humanities, Vol. 4(1), S/No 13, January, 2015:18-30 ISSN: $2225-$ 8590 (Print) ISSN 2227-5452 (Online) DOI: http://dx.doi.org/10.4314/ijah.v4i1.2 Studies.

45. Tarfa, A. (2011), Political Economy of NigeriaChina Relations, 1999-2010. An M.Sc. Project

46. Theotonio, D. S. (1970). The structure of dependence. American Economic Review 60, May, 231-36

47. ThisDay Newspaper (Wednesday, July 7, 2010). Zamfara, Chinese Firms Seal \$250m Solid Mineral Deals.

48. ThisDay Newspaper (Friday August 27, 2010). Federal Government Spends $\$ 12$ billion on Power and Rail Problems.

49. Tinbergen, J. (1962). Shaping the World Economy: Suggestions for an International Economic Policy. The Twenty century fund, New York.

50. Todaro, M. (2011), Economic Development (11th Edition). Wesley: Education and Addison

51. Tovonjatoro, S., \& Yinguo, D. (2015). Determinants of Export Growth rate: The case of Madagascar. International Journal of Economics and Finance, 7(9), 105-111.

52. Udala, S O. (2010). Nigeria-China Economic Relations under the south-south Cooperation. African Journal of International Affairs, 13(1\&2), 61-88.

53. Udeala, O. (2008). Foreign policy and the Nigerian image project: Constraints and challenges. The Nigerian Forum, Vol. 29, Nos.1112: November-December p.72.

54. Utomi, P. (1998), Managing Uncertainty: Competition and Strategies in Emerging Economies. Ibadan: Spectrum Books

55. Utomi, P. (2007). "Nigeria-China in Common Market' This Day, July 22

56. Utomi, P. (2008), China and Nigeria. Washington, DC: Centre for Strategic and International

57. Utomi, P. (2009). China and Nigeria http://africacenter.org/wpcontent/uploads/2009/10/01/ China-andNigeria.pdf.

58. Victor, H. (2003), Nigeria and China: Building Strong Economic Ties. Ibadan: Ibadan University Press

59. Vincent, F (2006), Dependency Theory: An Introduction. Mount College: South Hadley,

60. Wall, H. (1999). Using the gravity model to estimate the costs of protection. Review, Federal Reserve Bank of St.

61. World Bank (2004), "The Challenges of Financing Infrastructure in Developing Countries",

62. World Bank (2007), "Financial Flows to Developing Countries: Recent Trend and Prospects,"

63. World Bank (2007), Nigeria: Competitiveness and Growth (Country Economic Memorandum)

64. Zafar, A. (2006). The growing relationship between China and Sub-Saharan Africa http://www.chinadaily.com.cn/china/2006/04/30/c ontent-5777-832.htm 